\title{
Chronic Exposure of $\beta$ TC- 6 Cells to Supraphysiologic Concentrations of Glucose Decreases Binding of the RIPE3b1 Insulin Gene Transcription Activator
}

\author{
Vincent Poitout, L. Karl Olson, and R. Paul Robertson \\ Division of Diabetes, Endocrinology and Metabolism, University of Minnesota, Minneapolis, Minnesota 55455
}

\begin{abstract}
We have shown previously that chronic exposure of HITT15 cells to supraphysiologic glucose concentrations causes decreased insulin gene transcription and decreased binding activities of two $\beta$-cell specific transcription factors, STF-1 and the RIPE3b1 activator, and have suggested that these events may provide a mechanism for glucose toxicity on $\beta$-cell function. However, this contention can be criticized because it is not clear whether these observations are unique to the HIT-T15 cell or generalizable to other $\beta$-cell lines and the islet. Therefore, we cultured $\beta$ TC- 6 cells for up to $41 \mathrm{wk}$ in either 11.1 or $0.8 \mathrm{mM}$ glucose. We observed a passagedependent decrease in insulin content and insulin mRNA levels in $\beta$ TC- 6 cells chronically cultured in $11.1 \mathrm{mM}$ glucose. Cells chronically cultured in $0.8 \mathrm{mM}$ glucose had higher insulin mRNA levels than cells chronically cultured in $11.1 \mathrm{mM}$ glucose. The relative activity of a chloramphenicol acetyl transferase (CAT) reporter gene controlled by the 5 ' regulatory region of the human insulin gene was decreased in late passage $\beta$ TC- 6 cells chronically cultured in $11.1 \mathrm{mM}$ glucose, but was preserved in late passages of cells chronically cultured in $0.8 \mathrm{mM}$ glucose. Electromobility shift assays demonstrated that binding of a specific nuclear protein that recognizes the RIPE3b1 binding site of the insulin gene was markedly diminished in late passage cells chronically exposed to $11.1 \mathrm{mM}$ glucose, whereas binding activities of STF-1 and ICE activators were unchanged. RIPE3b1 binding activity was preserved in late passage cells chronically exposed to $0.8 \mathrm{mM}$ glucose. Mutation of the RIPE3b1 binding site almost completely abolished insulin gene transcription as well as binding activity. We conclude that chronic exposure of $\beta$ TC-6 cells to high glucose concentrations paradoxically decreases insulin gene transcription, in part, by decreasing activity of the trans-activating factor which binds to the RIPE3b1 sequence. This study uniquely demonstrates that altered binding to the RIPE3b1 sequence mediates glucose toxicity in $\beta$ TC-6 cells, thus rein-
\end{abstract}

Address correspondence to R. Paul Robertson, The Diabetes Center, Box 101 UMHC, 516 Delaware Street SE, Minneapolis, MN 55455. Phone: 612-626-1960; FAX: 612-626-3133. V. Poitout's present address is INSERM U341 Service de Diabétologie, Hôtel-Dieu, 1, Place du Parvis Notre-Dame, 75004 Paris, France. L.K. Olson's present address is Department of Physiology, Michigan State University, 108 Giltner Hall, East Lansing, MI 48824.

Received for publication 1 September 1995 and accepted in revised form 22 November 1995.

J. Clin. Invest.

(C) The American Society for Clinical Investigation, Inc.

0021-9738/96/02/1041/06 \$2.00

Volume 97, Number 4, February 1996, 1041-1046 forcing the importance of this cis-acting element in the regulation of insulin gene transcription. We conclude that the phenomenon of glucose toxicity decreasing binding of transcription factors and thereby reducing insulin gene expression is not a feature solely of HIT-T15 cells and may be demonstrable generally in $\beta$-cell lines. (J. Clin. Invest. 1996. 97:1041-1046.) Key words: glucose toxicity • insulin gene • transcription factor $\cdot$ RIPE3b1 • STF-1

\section{Introduction}

Glucose is the major physiologic stimulator of insulin secretion and biosynthesis, stimulates insulin gene transcription, and stabilizes insulin mRNA levels (reviewed in reference 1). However, we have observed that chronic exposure to supraphysiologic glucose concentrations can paradoxically and irreversibly decrease insulin gene transcription in HIT-T15 cells, a phenomenon more suggestive of glucose toxicity than glucose desensitization because the latter occurs more quickly and is reversible (2). HIT-T15 cells, an insulin-secreting cell line derived from SV40-transformed Syrian hamster islets of Langerhans, cultured in $11.1 \mathrm{mM}$ glucose for 25 passages lose their ability to secrete insulin in response to glucose and show decreased insulin content, insulin mRNA levels and insulin gene promoter activity (3-5). These changes are prevented by chronically culturing the cells in $0.8 \mathrm{mM}$ glucose (3-5). The decrease in insulin gene transcription is associated with diminished binding of a glucose-sensitive transcription factor, known as STF-1, to the insulin promoter $(5,6)$. STF-1 is a homeoprotein specifically expressed in the pancreas and the duodenum (7). STF-1 binds to the CT motifs (CTAATG) located at $-215 /-210$ (CT2 motif) and -82/-77 (CT1 motif) in the human insulin gene promoter (8), and its expression is required for normal pancreas development (9). Although the role of STF-1 in insulin gene regulation by glucose is still controversial, it is thought to be an important regulator of insulin gene transcription in vivo (10). We also demonstrated that loss of insulin gene transcription in HIT-T15 cells chronically cultured in high glucose concentrations is associated with decreased binding of a $\beta$-cell specific trans-activating factor to the RIPE3b1 cis-acting element of the rat insulin II gene (11). The RIPE3b1 sequence plays a key role in tissue specific expression of the insulin gene (12) and regulation of insulin gene transcription by glucose $(13,14)$. The trans-activating factors that interact with the RIPE3b1 element have not been isolated, and will be referred to as RIPE3b1-Act. In contrast, binding activity of the ICE/E1 activators (ICE/E1-Act), which are essential for tissue-specific and glucose-stimulated expression of the insulin gene (14), is not affected in HIT-T15 cells chronically cultured in $11.1 \mathrm{mM}$ glucose (11).

To evaluate whether these events might provide a general mechanism for glucose toxicity on $\beta$-cell function, it is necessary to ascertain whether our observations made in the HIT 
cell are or are not unique to this cell line. It is also essential to determine whether inactivity of one or both transcription factors, STF-1 and RIPE3b1-Act, is sufficient and necessary to mediate glucose toxic effects on the insulin gene. We used the $\beta$ TC- 6 cell line, which was derived from transgenic mice harboring the large $\mathrm{T}$ antigen of SV40 driven by the rat insulin II promoter $(15,16)$ and secretes insulin in response to glucose (17), to address three questions: (a) Does long term culture of $\beta$ TC-6 cells in supraphysiologic glucose concentrations lead to decreased insulin gene expression? If so, $(b)$ does long term culture of $\beta$ TC- 6 cells in low glucose concentrations preserve insulin gene expression, and, if so, (c) are these changes associated with decreased insulin gene transcription and binding of STF-1 and/or RIPE3b1-Act?

\section{Methods}

$\beta T C-6$ cells culture. The original culture of $\beta$ TC- 6 cells, developed by Efrat et al. (16), was provided by Norman Fleischer (Albert Einstein College of Medicine, Bronx, NY). Cells were grown in RPMI-1640 culture medium containing $10 \% \mathrm{FBS}$, in $5 \% \mathrm{CO}_{2} / 95 \%$ air at $37^{\circ} \mathrm{C}$. Medium was changed every $48 \mathrm{~h}$ and cells were passaged once weekly after detachment using trypsin-EDTA. Beginning at passage 35, $\beta$ TC- 6 cells were continuously cultured either in $0.8 \mathrm{mM}$ glucose, a slightly stimulatory concentration, or $11.1 \mathrm{mM}$ glucose, a maximal stimulatory concentration (17). Cell population doubling times were determined as reported previously (4).

Secretion studies. Static insulin secretion in response to increasing glucose concentrations, perifusion experiments, and determination of intracellular insulin content were performed as previously described (17).

Northern blot and slot blot analysis of insulin mRNA. $\beta$-TC- 6 cells were subcultured for $48 \mathrm{~h}$ in RPMI 1640 containing $11.1 \mathrm{mM}$ glucose by plating $5-10 \times 10^{6}$ cells in $60 \mathrm{~mm}$ culture dishes. Cells were rinsed with PBS (137 mM NaCl; $2.7 \mathrm{mM} \mathrm{KCl} ; 4.3 \mathrm{mM} \mathrm{NaH}{ }_{2} \mathrm{PO}_{4} .7 \mathrm{H}_{2} \mathrm{O}$; $\mathrm{pH}$ 7.3) and scraped with denaturing solution (4 $\mathrm{M}$ guanidine thiocyanate; $25 \mathrm{mM}$ sodium citrate, $\mathrm{pH} 7 ; 0.5 \%$ sarcosyl; $0.1 \mathrm{M} 2$-mercaptoethanol). The lysed cells were sonicated for $10 \mathrm{~s}$ at $50 \%$ duty to shear chromosomal DNA. RNA was isolated according to Chomczynski et al. (18). For Northern blot analysis, total RNA (5-15 $\mu \mathrm{g})$ was fractionated on a $1.5 \%$ agarose-formaldehyde gel and transferred to a nylon hybridization membrane $(0.22 \mu \mathrm{m}$; Micron Sps Inc., Westboro, MA) by electroblotting. The membrane was prehybridized in $50 \%$ formamide; $5 \times$ SSC; $5 \times$ Denhardt's; $50 \mathrm{mM}$ sodium phosphate; 0.1 $\mathrm{mg} / \mathrm{ml}$ salmon sperm DNA and $0.1 \%$ SDS at $42^{\circ} \mathrm{C}$ overnight, then hybridized for $16 \mathrm{~h}$ with ${ }^{32} \mathrm{P}$-labeled Syrian hamster preproinsulin cDNA probe (19) in the same solution. The membrane was then washed three times at room temperature in $2 \times$ SSC and $0.1 \%$ SDS, then twice at $60^{\circ} \mathrm{C}$ in $0.2 \times \mathrm{SSC}$ and $0.1 \%$ SDS, then exposed to $\mathrm{x}$-ray films (Kodak X-omat AR; Eastman Kodak Co., Rochester, NY) for 4-12 $\mathrm{h}$. Under the hybridization conditions used, the probe hybridized with a single $0.5-\mathrm{kb}$ band on agarose gel fractionation of total $\beta$ TC-6 cell RNA, consistent with $\beta$ TC cell insulin mRNA (16). For slot-blot analysis, total RNA $(2.5-5 \mu \mathrm{g})$ was loaded on a nylon hybridization membrane using the bio-dot apparatus (Bio Rad, Hercules, CA) and the membrane was prehybridized and hybridized as described above. Membranes were stripped for $2 \mathrm{~h}$ at $75^{\circ} \mathrm{C}$ in $1 \mathrm{mM}$ Tris-HCl, pH 8.0; 1 mM EDTA, pH 8.0 and $0.1 \times$ Denhardt's, and rehybridized with ${ }^{32} \mathrm{P}$-labeled human $\beta$-actin cDNA probe $(20)$ in order to control for variations in the amount of total RNA. Insulin and $\beta$-actin mRNA were quantitated by scanning densitometry of autoradiographs, and data are expressed as the density ratio of insulin mRNA to $\beta$-actin mRNA.

Rates of degradation of insulin and $\beta$-actin mRNA in $\beta$ TC- 6 cells chronically cultured in 0.8 or $11.1 \mathrm{mM}$ glucose were compared by incubating the cells in the presence of $5 \mu \mathrm{g} / \mathrm{ml}$ actinomycin D and har-
A

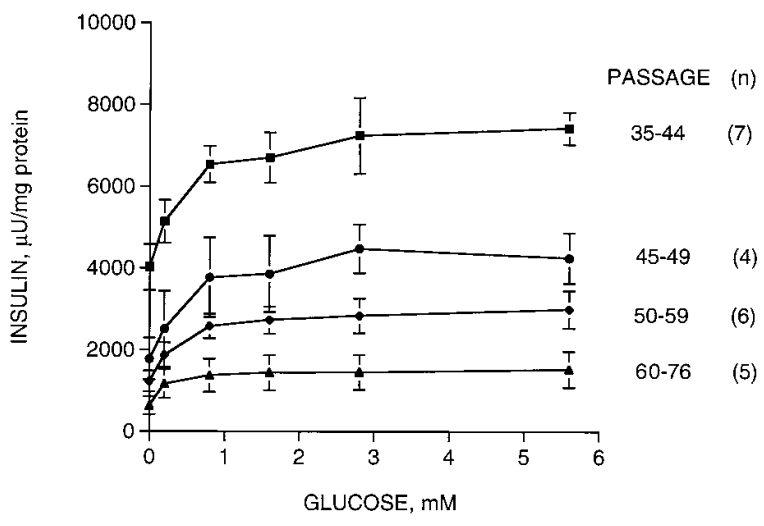

B

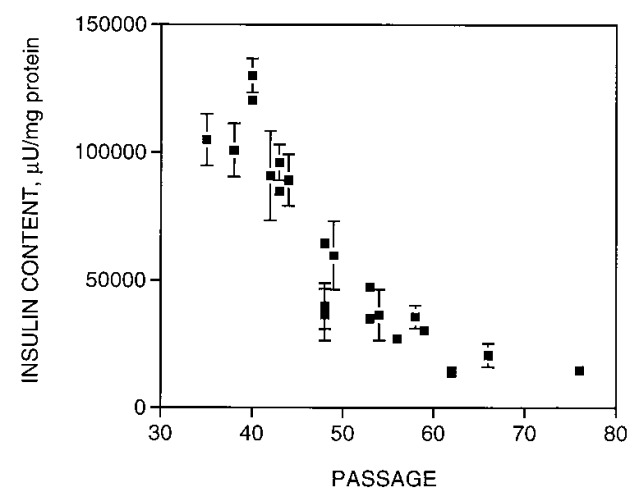

Figure 1. Glucose-induced insulin secretion $(A)$ and intracellular insulin $(B)$ in $\beta$ TC- 6 cells serially passaged in RPMI- 1640 containing $11.1 \mathrm{mM}$ glucose from passage 35 to 76 . (A) $\beta$ TC- 6 cells at various passages were incubated for $2 \mathrm{~h}$ in the presence of increasing glucose concentrations. Each curve represents the mean \pm SE for $n$ experiments performed in duplicate. Both basal and maximally stimulated insulin release gradually decreased as passage number increased (ANOVA; $P<0.0001$ ). (B) Intracellular insulin was measured after acidified ethanol extraction. Each datum represents the mean \pm SD for an individual experiment performed in duplicate. Intracellular insulin decreased as passage number increased (ANOVA; $P<0.0001$ ).

vesting samples for mRNA analysis $0,6,12$, and $24 \mathrm{~h}$ after the beginning of the incubation.

Cell transfections, CAT assay and luciferase assay. The plasmid INSCAT contains the human insulin gene sequences -326 to +30 linked to the chloramphenicol acetyl transferase (CAT) ${ }^{1}$ reporter gene (5). Insulin-luciferase constructs contain rat insulin II gene sequences spanning the region from -238 to +2 bp linked to the luciferase (LUC) reporter gene. The wild type $(-238$ WT LUC)(21) and the RIPE3b1 mutant ( $-238 \mathrm{~b} 1 \mathrm{~m}$ LUC)(14) were gifts from Dr. Roland Stein (Vanderbilt University, Nashville, TN).

$\beta$ TC- 6 cells were subcultured for $48 \mathrm{~h}$ in RPMI-1640 containing $11.1 \mathrm{mM}$ glucose at a density of $3 \times 10^{6}$ cells per well in six-well plates. Duplicate wells were transfected with $2 \mu \mathrm{g}$ of an insulin reporter construct or $0.5 \mu \mathrm{g}$ of RSVCAT or RSVLUC DNA by a liposome-mediated method (Lipofectin; BRL, Gaithersburg, MD). All transfections and subsequent incubations were performed in $11.1 \mathrm{mM}$ glucose. Cells were rinsed with FBS-free RPMI-1640, then $1 \mathrm{ml}$ of FBS-free RPMI-1640 containing 1:4 (wt/wt) plasmid DNA to lipofectin was added to each well. Cells were incubated for $4 \mathrm{~h}$ at $37^{\circ} \mathrm{C}$, after which the transfection media was replaced by $4 \mathrm{ml}$ of RPMI $1640.30 \mathrm{~h}$

1. Abbreviations used in this paper: CAT, chloramphenicol acetyl transferase; EMSA, electromobility shift assay; LUC, luciferase. 


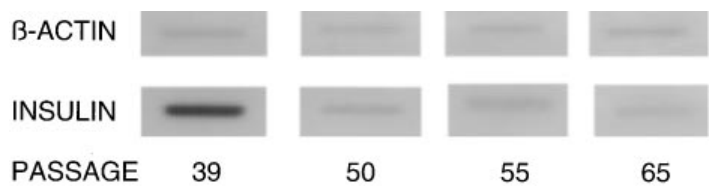

Figure 2. Slot blot analysis of insulin and $\beta$-actin mRNA levels in $\beta$ TC- 6 cells chronically cultured in $11.1 \mathrm{mM}$ glucose. Insulin mRNA was readily detectable at passage 39 , and was markedly diminished at passage 50 and higher. $\beta$-actin mRNA levels did not change over time.

after transfection, cells were harvested and CAT (22) or luciferase (23) activity was assayed. Data are expressed as relative insulin construct to RSV construct expression to control for variability in transfection efficiency observed between cells cultured in low and high glucose concentrations.

Nuclear extracts and ElectroMobility Shift Assays (EMSA). Nuclear extracts were prepared from $\beta$ TC- 6 cells as described by Abmayr and Workman (24). Double-stranded oligodeoxynucleotide probes containing the rat insulin II RIPE3b1 (-126 TGGAAACTGCAGCTTCAGCCCCTCT -101)(11), ICE (-104 TCTGGCCATCTGCTGATCCT -85$)(11)$ and the human insulin CT2 $(-230$ CCCCTGGTTAAGACTCTAATGACCCGCTGG -201)(6) were end-labeled with ${ }^{32} \mathrm{P}$-dCTP and the Klenow fragment of E. coli DNA polymerase I. The binding and electrophoresis conditions were performed according to Shih and Towle (25) except that $2 \mu \mathrm{g}$ poly(dI$\mathrm{dC}$ ) were used as a nonspecific competitor in the binding reaction. The competition experiments were performed with a double stranded oligodeoxynucleotide corresponding to a RIPE3b1 (-126 TGGAAACTGCAGCTCGAGCCCCTCT -101)(11) mutant binding site.

Expression of data and statistics. Data are presented as mean \pm SE. Intergroup comparisons were performed by Student's paired t-test or ANOVA when appropriate. $P<0.05$ was considered significant.

\section{Results}

Insulin secretion and gene expression in $\beta T C-6$ cells chronically cultured in $11.1 \mathrm{mM}$ glucose. $\beta$ TC-6 cells were chronically cultured in RPMI-1640 containing $11.1 \mathrm{mM}$ glucose from passage 35 to 76 . Insulin secretion was serially examined by static incubation with increasing glucose concentrations. Both basal and glucose-stimulated insulin release gradually decreased as the passage number increased (Fig. $1 A$ ). Similarly, intracellular insulin content from $\beta$ TC- 6 cells chronically cultured in 11.1 $\mathrm{mM}$ glucose gradually decreased over time (Fig. $1 B$ ).

Insulin mRNA levels in $\beta$ TC- 6 cells chronically cultured in $11.1 \mathrm{mM}$ glucose were serially assessed over the culture period by slot blot analysis. Insulin mRNA was readily detectable at passage 35 , and was markedly diminished at passage 50 and higher (Fig. 2).

Insulin gene expression in $\beta T C-6$ cells chronically cultured in 0.8 vs. $11.1 \mathrm{mM}$ glucose. To determine whether the observed decreased insulin gene expression was related to the glucose concentration in the media, $\beta$ TC- 6 cells were chronically cultured from passage 35 to 71 in RPMI-1640 containing either 0.8 or $11.1 \mathrm{mM}$ glucose. Cells chronically cultured in 0.8 or 11.1 $\mathrm{mM}$ glucose had similar population doubling times $(26.2 \pm 1.6$ vs. $25.5 \pm 1.6 \mathrm{~h}$ respectively, $n=2$ ). Insulin mRNA levels in $\beta$ TC- 6 cells chronically cultured in low and high glucose were compared by Northern blot or slot blot analysis. Insulin mRNA was more abundant in cells cultured in $0.8 \mathrm{mM}$ glucose than cells cultured in $11.1 \mathrm{mM}$ glucose (Fig. 3). To determine whether this was due to differences in mRNA stability, we
A

B
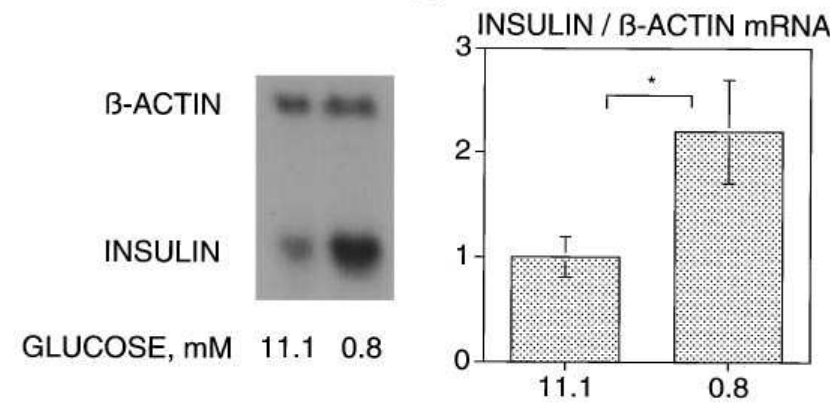

GLUCOSE, mM

Figure 3. Northern analysis of insulin mRNA in $\beta$ TC- 6 cells cultured in either 11.1 or $0.8 \mathrm{mM}$ glucose for $20-27 \mathrm{wk}$. $(A)$ Representative experiment performed at passage 57. (B) Densitometric analysis of insulin mRNA from 5 experiments performed at passage 55-62. Data are expressed as mean \pm SE relative density of insulin mRNA/ $\beta$-actin mRNA. Cells chronically cultured in $0.8 \mathrm{mM}$ glucose had more insulin mRNA than cells chronically cultured in $11.1 \mathrm{mM}$ glucose. $* P<0.05$.

compared insulin mRNA degradation rates by incubating the cells in the presence of $5 \mu \mathrm{g} / \mathrm{ml}$ actinomycin $\mathrm{D}$ and by measuring insulin mRNA levels $0,6,12$, and $24 \mathrm{~h}$ after the beginning of the incubation. $\beta$ TC- 6 cells from passage 43 , passage 62 chronically cultured in high glucose and passage 62 chronically cultured in low glucose had indistinguishable mRNA degradation rates under these conditions (Fig. 4).

Insulin gene promoter activity in $\beta T C-6$ cells serially passaged in $0.8 \mathrm{vs.} 11.1 \mathrm{mM}$ glucose. To determine whether the decrease in insulin gene expression in cells chronically cultured in $11.1 \mathrm{mM}$ glucose was associated with decreased insulin gene promoter activity, $\beta$ TC- 6 cells serially passaged in low or high glucose were transiently transfected with a CAT reporter gene driven by the $5^{\prime}$ regulatory region $(-326$ to +30$)$ of the human

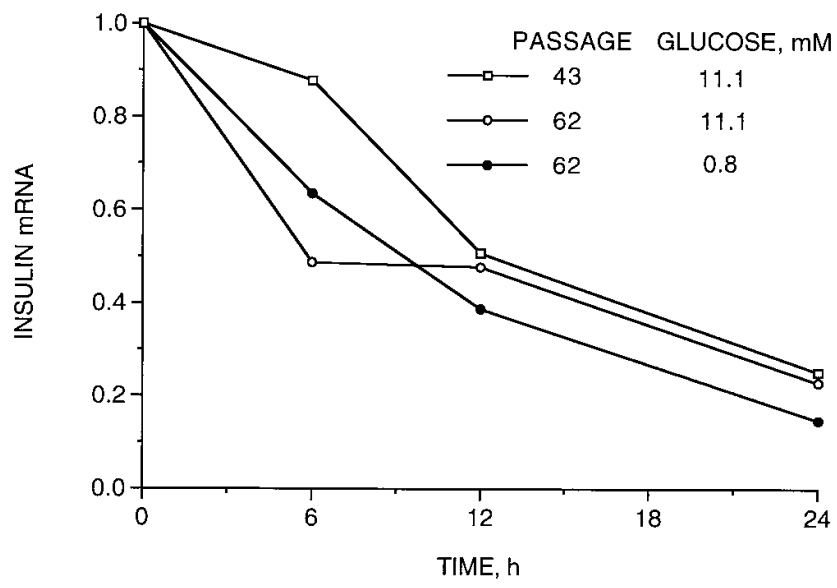

Figure 4. Comparison of insulin mRNA degradation rates in $\beta$ TC-6 cells at passage 43 , passage 62 cultured in $11.1 \mathrm{mM}$ glucose, and pasage 62 cultured in $0.8 \mathrm{mM}$ glucose. Cells were incubated in the presence of $5 \mu \mathrm{g} / \mathrm{ml}$ actinomycin D, and harvested for RNA extraction at times $0,6,12$, and $24 \mathrm{~h}$. Insulin and $\beta$-actin mRNA were analyzed by slot-blot. Data are expressed as the density of insulin mRNA over the density at time 0 . Similar results were obtained from a replicate experiment. 
insulin gene (Fig. 5). In early passages of $\beta$ TC- 6 cells the relative expression of INSCAT to RSVCAT was $1.00 \pm 0.12$. In late passages of $\beta$ TC- 6 cells cultured in $11.1 \mathrm{mM}$ glucose the relative INSCAT/RSVCAT expression was $0.59 \pm 0.14(P=$ $0.001, n=5$ ). In contrast, relative INSCAT/RSVCAT expression in late passage $\beta$ TC- 6 cells cultured in $0.8 \mathrm{mM}$ glucose was $1.02 \pm 0.23(P<0.01$ vs. cells chronically cultured in $11.1 \mathrm{mM}$ glucose; $n=5$ ). These data indicate that insulin promoter activity is decreased by $\sim 40 \%$ in $\beta$ TC- 6 cells chronically cultured in $11.1 \mathrm{mM}$ glucose compared to both early passage cells and late passage cells cultured in $0.8 \mathrm{mM}$ glucose.

Chronic exposure of $\beta$ TC- 6 cells to high glucose also led to a marked decrease in the activity of the rat insulin II promoter as determined by transient transfection with -238 WTLUC (see below).

Insulin gene 5'-regulatory region binding proteins in $\beta T C-6$ cells chronically cultured in $0.8 \mathrm{vs} .11 .1 \mathrm{mM}$ glucose. To determine whether the decreased promoter activity was associated with altered interaction between transcription factors and regulatory sequences of the insulin gene, nuclear proteins were extracted from early passage (P 42) and late passage (P 71) $\beta$ TC-6 cells cultured either in 0.8 or in $11.1 \mathrm{mM}$ glucose. Formation of specific DNA-protein complexes was detected by EMSA using oligodeoxynucleotide probes containing the RIPE3b1, CT2 and ICE/E1 elements. With the oligodeoxynucleotide probe containing the STF-1 binding sequence (CT2), a major complex was detected in early passage $\beta$ TC- 6 cells, late passage $\beta$ TC- 6 cells cultured in high glucose, and late passage $\beta$ TC- 6 cells cultured in low glucose (Fig. 6 A, lanes 1-3), and the intensity of the binding was similar in the three cell extracts. Similarly, nuclear extracts from early passage $\beta$ TC- 6 cells and late passage $\beta$ TC- 6 cultured in low and high glucose shifted the oligodeoxynucleotide probe containing the ICE/E1 element to similar extent (Fig. $6 A$, lanes $4-6$ ). The oligodeoxynucleotide probe containing the RIPE3b1 sequence formed a single complex in early passages $\beta$ TC-6 cells (Fig. 6 A, lane 7).

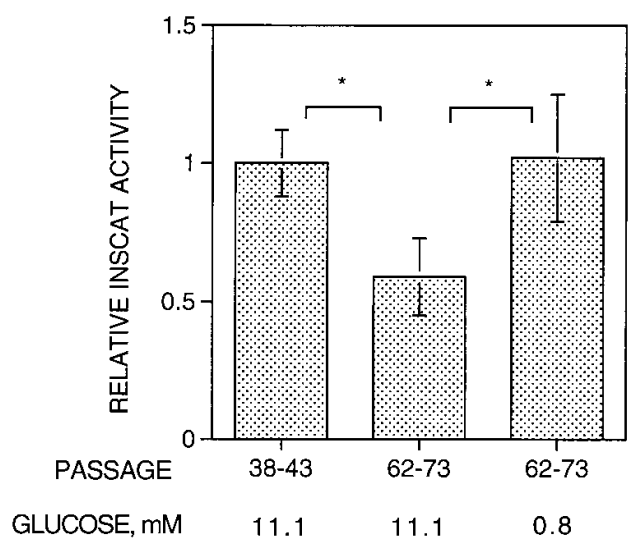

Figure 5. Early passages (38-43) of $\beta$ TC- 6 cells or late passages (6273 ) of $\beta$ TC- 6 cells cultured in either 11.1 or $0.8 \mathrm{mM}$ glucose were transiently transfected with INSCAT. The relative expressions of INSCAT to RSVCAT are normalized to expression observed in early passage $\beta$ TC- 6 cells. Late passages of cells chronically cultured in $11.1 \mathrm{mM}$ glucose had decreased INSCAT activity as compared to early passage cells. In contrast, INSCAT activity was preserved in late passage cells chronically cultured in $0.8 \mathrm{mM}$ glucose. Data represent the mean $\pm \mathrm{SE}$ for five independent experiments with duplicate observations $(n=5) . * P<0.01$.

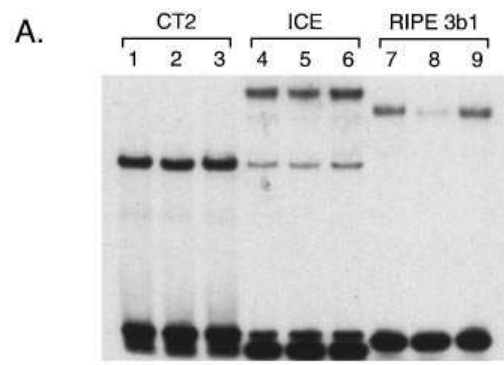

B.

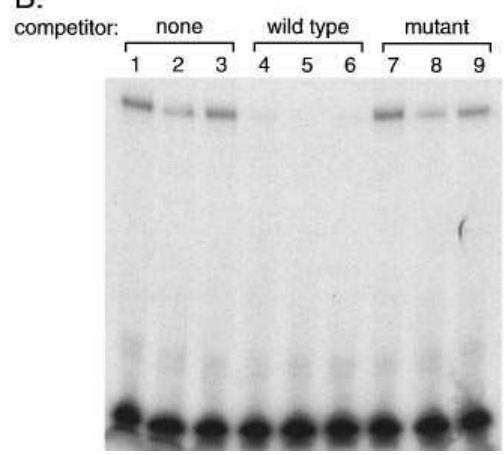

Figure 6. EMSA analysis of nuclear extracts from early passage of $\beta$ TC- 6 cells and late passage of $\beta$ TC- 6 cells chronically cultured in 0.8 or $11.1 \mathrm{mM}$ glucose. (A) EMSA using ${ }^{32} \mathrm{P}$ labeled sequences to the CT2 (lanes 1-3), ICE/E1 (lanes 4-6), and RIPE3b1 (lanes 7-9) binding sites. Lanes 1, 4, and 7: nuclear extract from $\beta$ TC- 6 cells passage 42. Lanes 2, 5, and 8: nuclear extract from $\beta$ TC-6 cells passage 71 chronically cultured in $11.1 \mathrm{mM}$ glucose. Lanes 3, 6, and 9: nuclear extract from $\beta$ TC-6 cells passage 71 chronically cultured in $0.8 \mathrm{mM}$ glucose. Using oligodeoxynucleotides to the RIPE3b1 sequence, a major DNA/protein complex was present in early passage cells and late passage cells cultured in $0.8 \mathrm{mM}$ glucose (lanes 7 and 9 ), but was reduced in late passage cells cultured in $11.1 \mathrm{mM}$ glucose (lane 8 ). (B) EMSA using ${ }^{32} \mathrm{P}$-labeled sequence to the RIPE3b1. Lanes 1, 4, and 7: nuclear extract from $\beta$ TC-6 cells passage 42. Lanes 2, 5, and 8: nuclear extract from $\beta$ TC- 6 cells passage 71 chronically cultured in $11.1 \mathrm{mM}$ glucose. Lanes 3, 6, and 9: nuclear extract from $\beta$ TC- 6 cells passage 71 chronically cultured in $0.8 \mathrm{mM}$ glucose. Competitor added: lanes 4-6: 200 fold excess of unlabeled wild type sequence; lanes 7-9: 200-fold excess of unlabeled mutant sequence. Similar results were obtained for two independent experiments for each condition.

In contrast to STF-1 and ICE/E1-Act, the RIPE3b1 complex was markedly reduced in late passage $\beta$ TC- 6 cells cultured in $11.1 \mathrm{mM}$ glucose (Fig. $6 \mathrm{~A}$, lane 8 ), but was preserved in late passage $\beta$ TC-6 cells chronically cultured in $0.8 \mathrm{mM}$ glucose (Fig. $6 A$, lane 9). Similar results were obtained in a replicate experiment performed with nuclear extracts from $\beta$ TC- 6 cells at passage 36 and 67 cultured in 0.8 or $11.1 \mathrm{mM}$ glucose. The specificity of the binding to the RIPE3b1 sequence was analyzed in competition experiments using excess unlabeled wild type or mutant oligodeoxynucleotide to compete for binding (Fig. 6 B, lanes 4-9). The protein-DNA complex was competed by the unlabeled wild-type sequence (Fig. $6 B$, lanes 4-6), but not by the mutant sequence (Fig. $6 B$, lanes 7-9). The mutant RIPE3b1 sequence containing a 2-bp substitution has been shown to eliminate its activity both in vitro and in vivo (13). These results indicate that binding to the RIPE3b1, but not to the CT2 and ICE/E1, element is reduced in late-passage $\beta$ TC-6 cells cultured in $11.1 \mathrm{mM}$ glucose.

Expression of $-238 W T L U C$ and $-238 b 1 m L U C$ constructs in $\beta T C-6$ cells. To determine whether the decreased binding of RIPE3b1-Act could account for the diminished promoter activity, cells were transiently transfected with either -238WTLUC or a $-238 \mathrm{~b} 1 \mathrm{mLUC}$ construct containing the mutation described above (Fig. 7). Expression of -238WTLUC was reduced in late passage $\beta$ TC- 6 cells cultured in $11.1 \mathrm{mM}$ glucose as compared to early passage cells, and was preserved in 


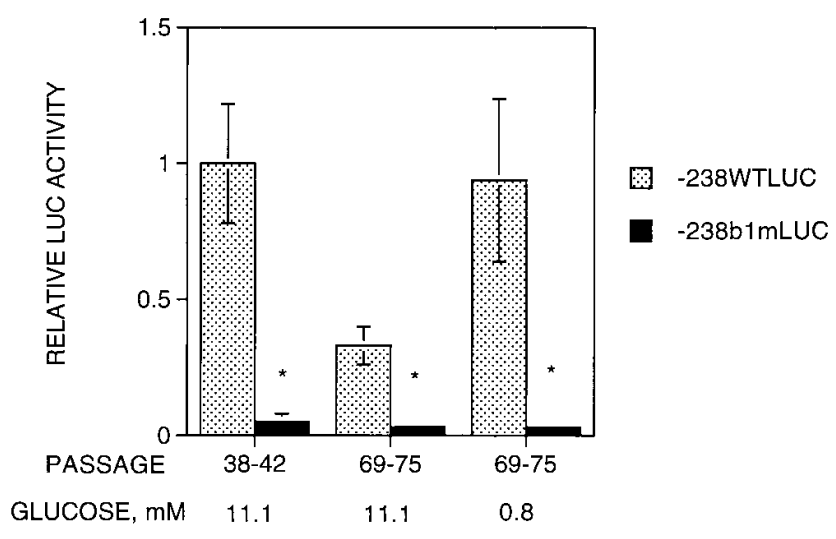

Figure 7. Functional analysis of the RIPE3b1 binding site. Early passages of $\beta$ TC- 6 cells or late passages of $\beta$ TC- 6 cells cultured in 0.8 or $11.1 \mathrm{mM}$ glucose were transiently transfected with either the wild type vector -238 WTLUC or the mutant vector $-238 \mathrm{~b} 1 \mathrm{mLUC}$. The relative $-238 \mathrm{LUC} / \mathrm{RSVLUC}$ expressions were normalized to the expression observed in early passage cells. Mutation of the RIPE3b1 binding site almost abolished the insulin promoter expression in all three conditions. Data represent the mean \pm SE for four independent experiments with duplicate observations $(n=4) .{ }^{*} P<0.05$ vs. wild type vector.

late passage cells cultured in $0.8 \mathrm{mM}$ glucose. These observations, using a rat insulin II promoter, confirm the results obtained with the human insulin promoter INSCAT (see above). Expression of $-238 \mathrm{~b} 1 \mathrm{mLUC}$ was markedly decreased in early passage $\beta$ TC- 6 cells as well as in late passage $\beta$ TC- 6 cells cultured in either 0.8 or $11.1 \mathrm{mM}$ glucose. These data indicate that loss of RIPE3b1 binding activity can lead to the observed decrease in insulin gene promoter activity.

\section{Discussion}

This study was designed to determine whether chronic exposure of $\beta$ TC- 6 cells to supraphysiologic glucose concentrations would adversely affect insulin gene expression. We found that $\beta$ TC- 6 cells chronically cultured in $11.1 \mathrm{mM}$ glucose have decreased insulin secretion, insulin content and insulin mRNA levels, and that cells chronically cultured in $0.8 \mathrm{mM}$ glucose have higher levels of insulin mRNA than cells chronically cultured in $11.1 \mathrm{mM}$ glucose. The decrease in insulin mRNA levels in cells chronically cultured in $11.1 \mathrm{mM}$ glucose is associated with reduced insulin gene transcription and diminished binding to the RIPE3b1 cis-acting element. Both are preserved by culturing the cells in $0.8 \mathrm{mM}$ glucose.

These results agree with those we previously reported in the HIT-T15 cell (4), and reinforce our contention that chronic exposure of $\beta$-cells to a supraphysiologic glucose concentration adversely affects insulin gene expression. $\beta$ TC-6 cells chronically cultured in the presence of $0.8 \mathrm{mM}$ glucose plus $10.3 \mathrm{mM}$ mannitol have similar levels of insulin mRNA compared to cells cultured in $0.8 \mathrm{mM}$ glucose only (data not shown), indicating that deleterious effects of supraphysiologic glucose are not due to differences in osmolarity of the culture media. The rate of degradation of insulin mRNA is similar in early passage $\beta$ TC- 6 cells, late passage cells cultured in low glucose, and late passage cells cultured in high glucose, suggesting that the observed decrease in insulin mRNA levels in late passage cells cultured in high glucose reflects a diminution in the rate of transcription. Accordingly, expression of human insulin and rat insulin II promoters is diminished by $\sim 40 \%$ in these cells, and is preserved by culturing the cells in low glucose concentration. These observations are also in accordance with those previously reported in HIT cells (5).

STF-1, RIPE3b1-Act and ICE/E1-Act have been shown to play important roles in the control of insulin gene transcription. We have previously demonstrated that chronic culture of HIT cells in high glucose concentrations is associated with decreased binding of STF-1 and RIPE3b1-Act, whereas ICE/E1Act binding is unchanged $(5,6,11)$. The results we now report indicate that continuous culture of $\beta$ TC- 6 cells in high glucose concentrations leads to decreased binding activity of the RIPE3b1-Act to its cognate sequence with no alteration in STF-1 binding activity. In addition, mutation of the RIPE3b1 sequence almost abolishes insulin gene transcription in $\beta$ TC-6 cells. It is therefore reasonable to conclude that decreased binding of RIPE3b1-Act is responsible for the decrease in insulin promoter activity observed in $\beta$ TC- 6 cells chronically cultured in high glucose concentrations. Further culture of $\beta$ TC- 6 cells in high glucose for an additional 8 passages does not lead to decreased STF-1 binding (data not shown). This preserved binding of STF-1 in $\beta$ TC-6 cells prompted us to question whether decreased RIPE3b1-Act binding activity precedes the loss of STF-1 binding activity in HIT cells. Nuclear extracts from various passages of HIT cells chronically cultured in 0.8 or $11.1 \mathrm{mM}$ glucose were isolated, and EMSAs were performed using oligodeoxynucleotide probes to the RIPE3b1 and CT2 sequences. Both binding activities decreased simultaneously (data not shown). Consequently, this study uniquely provides a model for glucose toxicity in which RIPE3b1-Act, but not STF1, binding activity is affected, and reinforces the importance of reduced RIPE3b1-Act binding activity in mediating toxic effects of glucose on the insulin gene. Elucidation of the mechanism by which RIPE3b1-Act binding activity is altered awaits the isolation and characterization of this activator.

Chronic hyperglycemia is thought to play a secondary role in the pathogenesis of Type II diabetes (reviewed in references 26 and 27). Studies in Type II diabetic patients have demonstrated that defective glucose-induced insulin release can be partially reversed by normalization of blood glucose levels (28, 29). Eizirik et al. (30) observed diminished insulin content from human islets cultured in high glucose concentrations for $7 \mathrm{~d}$. These changes were partially reversed by subsequent culture in lower glucose concentrations. Orland and Permutt (31) observed a diminution in both insulin content and mRNA levels in $d b / d b$ mice after several weeks of hyperglycemia. However, in vitro studies utilizing primary $\beta$-cells can only be conducted over relatively limited periods of time, and experiments using animals do not allow for harvesting large amounts of material needed for investigation of insulin gene transcription. Alternatively, the use of insulin-secreting cell lines permits an assessment of the effects of chronic exposure to high glucose on insulin gene transcription. Our previous studies in the HITT15 cell have demonstrated that chronic exposure to supraphysiologic glucose concentrations is associated with decreased insulin gene transcription and decreased binding activities of both transcription factors STF-1 and RIPE3b1-Act. We now report that insulin gene expression and transcription are also diminished in $\beta$ TC- 6 cells chronically exposed to supraphysiologic glucose concentrations. These alterations are associated with, and likely to be caused by, decreased ability to form a 
specific protein/DNA complex with the RIPE3b1 cis-acting element. These observations suggest that reduced binding activity of RIPE3b1-Act by itself can mediate glucose toxicity on the insulin gene, and may provide insights into the mechanism by which hyperglycemia contributes to $\beta$-cell dysfunction in Type II diabetes.

\section{Acknowledgments}

We thank Dr. Roland Stein for providing the ICE and RIPE3b1 oligodeoxynucleotide probes and the luciferase constructs. We gratefully acknowledge the excellent technical assistance of Elizabeth Oseid.

This work was supported by National Institutes of Health grants R01-DK-38325 (to R.P. Robertson) and 5F32-DK-08742 (to L.K. Olson). V. Poitout was supported in part by a Fellowship from the Association de Langue Française pour l'Etude du Diabète et des Maladies Métaboliques.

\section{References}

1. Docherty, K., A.R. Clark, V. Scott, and S.W. Knight. 1991. Metabolic control of insulin gene expression and biosynthesis. Proc. Nutr. Soc. 50:553-558.

2. Robertson, R.P., L.K. Olson, and H.J. Zhang. 1994. Differentiating glucose toxicity from glucose desensitization: a new message from the insulin gene. Diabetes. 43:1085-1089.

3. Zhang, H.J., T.F. Walseth, and R.P. Robertson. 1989. Insulin secretion and cAMP metabolism in HIT cells. Reciprocal and serial passage-dependent relationships. Diabetes. 38:44-48.

4. Robertson, R.P., H.J. Zhang, K.L. Pyzdrowski, and T.F. Walseth. 1992. Preservation of insulin mRNA levels and insulin secretion in HIT cells by avoidance of chronic exposure to high glucose concentrations. J. Clin. Invest. 90:320-325.

5. Olson, K.O., J.B. Redmon, H.C. Towle, and R.P. Robertson. 1993. Chronic exposure of HIT cells to high glucose concentrations paradoxically decreases insulin gene transcription and alters binding of insulin gene regulatory protein. J. Clin. Invest. 92:514-519.

6. Olson, L.K., A. Sharma, M. Peshavaria, C.V.E. Wright, H.C. Towle, R.P. Robertson, and R. Stein. 1995. Reduction of insulin gene transcription in HITT15 cells chronically exposed to a supraphysiologic glucose concentration is associated with loss of STF-1 transcription factor expression. Proc. Natl. Acad. Sci. USA. 92:9127-9131.

7. Miller, C.P., R.E. McGehee, Jr., and J.F. Habener. 1994. IDX-1: a new homeodomain transcription factor expressed in rat pancreatic islets and duodenum that transactivates the somatostatin gene. EMBO (Eur. Mol. Biol. Org.) J. 13:1145-1156.

8. Boam, D.S.W. and K. Docherty. 1989. A tissue-specific nuclear factor to multiple sites in the human insulin gene enhancer. Biochem. J. 264:233-239.

9. Jonsson, J., L. Carlsson, T. Edlund, and H. Edlund. 1994. Insulin-promoter factor 1 is required for pancreatic development in mice. Nature (Lond.). 371:606-609.

10. Ohlsson, H., K. Karlsson, and T. Edlund. 1993. IPF-1, a homeodomaincontaining transactivator of the insulin gene. EMBO (Eur. Mol. Biol. Organ.) J. 12:4251-4259.

11. Sharma, A., L.K. Olson, R.P. Robertson, and R. Stein. 1995. The reduction of insulin gene transcription in HIT-T15 $\beta$ cells chronically exposed to high glucose concentration is associated with the loss of RIPE3b1 and STF-1 transcription factor expression. Mol. Endocrinol. 9:1127-1134.
12. Hwung, Y.-P., Y.-Z. Gu, and M.-J. Tsai. 1990. Cooperativity of sequence elements mediates tissue specificity of the rat insulin II gene. Mol. Cell. Biol. 10(4):1784-1788.

13. Shieh, S.-Y., and M.-J. Tsai. 1991. Cell-specific and ubiquitous factors are responsible for the enhancer activity of the rat insulin II gene. J. Biol. Chem. 266(25):16708-16714.

14. Sharma, A., and R. Stein. 1994. Glucose-induced transcription of the insulin gene is mediated by factors required for $\beta$-cell-type-specific expression. Mol. Cell. Biol. 14(2):871-879.

15. Hanahan, D. 1985. Heritable fromation of pancreatic $\beta$-cell tumours in transgenic mice expressing recombinant insulin/SV-40 oncogenes. Nature (Lond.). 315:115-122.

16. Efrat, S., S. Linde, H. Kofod, D. Spector, M. Delannoy, S. Grant, D. Hanahan, and S. Baekkeskov. 1988. Beta-cell lines derived from transgenic mice expressing a hybrid insulin gene-oncogene. Proc. Natl. Acad. Sci. USA. 85: 9037-9041.

17. Poitout, V., L.E. Stout, M.A. Armstrong, T.F. Walseth, R.L. Sorenson, and R.P. Robertson. 1995. Morphological and functional characterization of $\beta$ TC- 6 cells, an insulin-secreting cell line derived from transgenic mice. Diabetes. 44:306-313.

18. Chomczynski, P., and N. Sacchi. 1987. Single-step method of RNA isolation by acid guanidium thiocyanate-phenol-chloroform extraction. Anal. Biochem. 162:156-159.

19. Bell, G.I., and R. Sanchez-Pescador. 1984. Sequence of a cDNA encoding Syrian Hamster preproinsulin. Diabetes. 33:297-300.

20. Gunning, P., P. Ponte, H. Okayama, J. Engel, H. Blau, and L. Kedes. 1983. Isolation and characterization of full-length cDNA clones for human ab- and g-actin mRNAs: skeletal but not cytoplasmic actins have an amino-terminal cysteine that is subsequently removed. Mol. Cell. Biol. 3:787-795.

21. Robinson, G.L.W.G., M. Peshavaria, E. Henderson, S.-Y. Shieh, M.-J. Tsai, G. Teitelman, and R. Stein. 1994. Analysis of transcription regulatory signals of the insulin gene: expression of the trans-active factor that stimulates insulin control element mediated expression precedes insulin gene transcription. J. Biol. Chem. 269:2452-2460.

22. Kingston, R.E., and J. Sheen. 1991. Introduction of DNA into mammalian cells. In Current Protocols in Molecular Biology. F. Ausubel, R. Brent, R. Kingston, D. Moore, J. Seidman, J. Smith, and K. Struhl, editors. Greene Publishing Associates and Wiley-Interscience, New York. 9.0.1-9.9.6.

23. De Wet, J.R., K.V. Wood, M. De Luca, D.R. Helinski, and S. Subramani. 1987. Firefly luciferase gene: Structure and expression in mammalian cells. Mol. Cell. Biol. 7:725-737.

24. Abmayr, S.M., and J.L. Workman. 1991. DNA-protein interactions. In Current Protocols in Molecular Biology. F. Ausubel, R. Brent, R. Kingston, D. Moore, J. Seidman, J. Smith, and K. Struhl, editors. Greene Publishing Associates and Wiley-Interscience, New York. 12.0.1-12.1.9.

25. Shih, H.-M., and H.C. Towle. 1992. Definition of the carbohydrate response element of the rat S14 gene. J. Biol. Chem. 267:13222-13228.

26. Robertson, R.P. 1989. Type II diabetes, glucose "non-sense," and islet desensitization. Diabetes. 38:1501-1505.

27. Unger, R.H., and S. Grundy. 1985. Hyperglycemia as an inducer as well as a consequence of impaired islet cell function and insulin resistance: implications for the management of diabetes. Diabetologia. 28:119-121.

28. Turner, R.C., S.T. McCarthy, R.R. Holman, and E. Harris. 1976. Betacell function improved by supplementing basal insulin secretion in mild diabetes. Br. Med. J. 1:1252-1254.

29. Vague, P., and J.-P. Moulin. 1982. The defective glucose-sensitivity of the $\beta$-cell in non-insulin-dependent diabetes: improvement after twenty hours of normoglycemia. Metabolism. 31:139-142.

30. Eizirik, D.L., G.S. Korbutt, and C. Hellerstrom. 1992. Prolonged exposure of human pancreatic islets to high glucose concentrations in vitro impairs the $\beta$-cell function. J. Clin. Invest. 90:1263-1268.

31. Orland, M.J., and M.A. Permutt. 1987. Quantitative analysis of pancreatic proinsulin mRNA in genetically diabetic $(d b / d b)$ mice. Diabetes. 37:341-347. 